\title{
Clifford, William Kingdon
}

Luis R.G. Oliveira

University of Houston, USA

W.K. Clifford (1845-1879) was a British mathematician, philosopher, and public intellectual, most famous for his widely anthologized essay "The Ethics of Belief." Originally addressed to the Metaphysical Society in 1876, the essay contains one of the most memorable lines in the history of philosophy: "it is wrong always, everywhere, and for anyone, to believe anything upon insufficient evidence." This is a moralized version of what is known in epistemology as EVIDENTIALISM. Clifford was educated at Trinity College, Cambridge; taught at University College, London; was a Fellow of the Royal Society; and died of tuberculosis at the young age of 33.

Clifford was the youngest member ever elected to the Metaphysical Society, which was founded for the purpose of addressing a cultural crisis. Due to academic developments in biblical criticism, the publication of Charles Darwin's (see DARWIN, CHARLES) work, and the influence of Herbert Spencer's philosophy, many Victorians thought the grounds beneath religious and moral institutions were eroding away. In his celebrated lectures and publications, Clifford addressed himself to this very crisis and was enthusiastic about three central claims: (i) his aforementioned endorsement of evidentialism on moral grounds; (ii) the challenge he thought evidentialism posed to religious belief of any kind; and (iii) the appropriateness of the scientific method as an alternative guide to social progress and moral truth.

In his famous 1876 address (published in 1877), Clifford focuses on the direct and indirect negative consequences of ungrounded beliefs - beliefs that are not based on the available evidence - and on our moral duty to prevent them. Such consequences include: (i) the prevention of diligent inquiry in the future, by virtue of having begun a habit of careless belief-formation; (ii) the promotion of further ungrounded beliefs, since any further belief grounded on an ungrounded belief will be ungrounded as well; (iii) the inevitable loss of honor once those beliefs lead to action, for one commits a "sin against mankind" if one inflicts on others the risks resulting from ungrounded belief; (iv) the social damage caused by false beliefs, which are propagated by believing on insufficient evidence; (v) the poisoning of humanity's intellectual "common property," which was entrusted to us by the previous generation; and (vi) the production of people much more willing to deceive, since forming ungrounded beliefs is a clear sign to others that I myself do not care about the truth. Because of such inescapable negative consequences, Clifford takes it that we have a moral duty to believe in accordance with our evidence. With this duty as his background, Clifford then outlines conditions for accepting testimony and for making inferences that go beyond our own experiences in a thinly veiled critique of religious beliefs. 
Despite its historical pedigree and influence, however, some philosophers working on the epistemology of religion have pushed back against Clifford's evidentialism. William James (see JAMES, WILLIAM), for example, is the author of the most influential counter-piece to Clifford's famous address. According to James (1896), Clifford simply ignores the amount of nonevidential factors that determine what we take as our evidence and what we take as good enough of it. For James, these are psychological factors owing to our "passional tendencies and volitions." James also argues that on matters of great importance that remain undecided by the evidence - religious matters in particular - there is nothing about our evidence that can dictate which of the twin goals of belief-formation we must prioritize: believing what is true or not believing what is false. In these two ways, James attempts to expose Clifford's ascetic evidentialism as just one amongst many policies of belief-formation from which we may "lawfully" choose.

Today, even some who share Clifford's evidentialism have nonetheless been critical of his appeal to morality as its justifying grounds. The worry is that some simple counterexamples seem to reveal morally innocent ungrounded beliefs. Richard Feldman (2006) has argued that such counterexamples arise in cases where believing against the evidence is lifesaving and nothing else seems to hang in the balance. Perhaps a patient in critical care will increase her chances of survival by a nontrivial degree if she believes, against the evidence, that she is very likely to recover. Susan Haack (2001) has also argued that sometimes believing against the evidence is simply trivial and isolated. Perhaps a certain shopper quite uncritically believes, against the evidence, that the apples she just picked are the best apples in the supermarket. For these contemporary "Cliffordians," therefore, a proper defense of evidentialism requires a focus on the "epistemic point of view" as a distinct normative domain from the "practical point of view." Yet Clifford's sense of a moral duty to believe the truth is not a relic of epistemology's past. Stephen Grimm (2009), for example, follows Clifford in claiming that we have a moral duty "not to be cavalier when we form beliefs" since we are potential sources of information on every subject matter to others who might care about it a great deal.

Though I myself have been critical of evidentialism, of Clifford, and of Cliffordians (see Oliveira 2017 and 2018), my engagement with his ideas and this tradition evinces my respect for them. By all contemporaneous accounts, Clifford was a man of great intelligence, wit, and social grace. His lectures and essays were well received in his time, and the best of these are still well regarded and much discussed today. Few in history can boast of such achievements in such a short life.

See also: DARWIN, CHARLES; ETHICS OF BELIEF; EVIDENTIALISM; FIDEISM; JAMES, WILLIAM; REFORMED EPISTEMOLOGY

\section{REFERENCES}

Clifford, W.K. 1877. “The Ethics of Belief.” Contemporary Review, XXXIX January edition. 
Feldman, Richard. 2006. “Clifford's Principle, James' Options.” Social Epistemology, 20 (1): 19-33.

Grimm, Stephen. 2009. "Epistemic Normativity.” In Epistemic Value, edited by Adrian Haddock, Alan Millar, and Duncan Pritchard, 243-264. Oxford: Oxford University Press.

Haack, Susan. 2001. “The Ethics of Belief Reconsidered." In Knowledge, Truth, and Duty: Essays on Epistemic Justification, Responsibility, and Virtue, edited by Matthias Steup, 21-33. Oxford: Oxford University Press.

James, William. 1896. “The Will to Believe.” The New World, 5: 327-347.

Oliveira, L.R.G. 2017. "Deontological Evidentialism, Wide Scope, and Privileged Values." Philosophical Studies, 174 (2): 485-506.

Oliveira, L.R.G. 2018. “Deontological Evidentialism and Ought Implies Can.” Philosophical Studies, 175 (10): 2567-2582.

\section{FURTHER READING}

Adler, Jonathan E. 2002. Belief's Own Ethics. Cambridge, MA: MIT Press.

Clifford, W.K. 1999. The Ethics of Belief and Other Essays. Amherst: Prometheus Books.

Dougherty, Trent. 2011. Evidentialism and Its Discontents. Oxford: Oxford University Press.

Feldman, Richard. 2001. "The Ethics of Belief." Philosophy and Phenomenological Research, 60 (3): 667-695.

Madigan, Timothy J. 2009. W.K. Clifford and the "The Ethics of Belief." Cambridge: Cambridge Scholars Publishing.

Matheson, Jonathan, and Rico Vitz. 2014. The Ethics of Belief. Oxford: Oxford University Press. 